\title{
Waste management in the oil and gas industry by Brazilian Guideline for Environmental Audits - DZ-056-R.3
}

\author{
Eva .C. S. Nunes, Assed N. Haddad \\ Universidade Federal do Rio de Janeiro, UFRJ, Rio de Janeiro, Brazil \\ Email address: \\ eva.nunes@poli.ufrj.br(E. Nunes), assed@poli.ufrj.br(A. Haddad)
}

\section{To cite this article:}

Eva .C. S. Nunes, Assed N. Haddad. Waste Management in the Oil and Gas Industry by Brazilian Guideline for Environmental Audits DZ-056-R.3. American Journal of Environmental Protection. Vol. 2, No. 6, 2013, pp. 170-175. doi: 10.11648/j.ajep.20130206.18

\begin{abstract}
Oil and gas exploration and production (E\&P) is the main activity for the offshore economy. Yet, this it is also responsible for many of the major environmental accidents. Environmental legislation acts strongly in this type of activity, through limitations in the exploration processes and control procedures for the generation, storage, transportation and disposal of waste, applying penalties in cases of non-conformances, such as oil spills at sea and air pollutants emissions. In this context, waste management is very important for these operations, because of the complexity and dangerousness with the waste generated, and the cost of their destination. This work presents the offshore waste management system, introducing the procedures and controls according the requirements of the Brazilian Guideline for Environmental Audits, DZ-056-R.3.
\end{abstract}

Keywords: Waste Management, Oil and Gas Exploration and Production, Brazilian Guideline for Environmental Audits, DZ-056-R.3, Environmental Damage

\section{Introduction}

Along the last few years, advances in legislation provide greater controls and environmental requirements, mainly with waste. In this context, waste management system has been applied in many types of buildings, which need to attend a series of requirements, according to the risks involving their activities [1].

Companies need to perform a sequence of actions to create a complete system of waste management. They have to respect the applicable law, invest in technological resources, equipment, logistic and operational processes. And further establish several procedures of QHSE (quality, health, safety and environment), like controls, measurements and monitoring of all activities, emergency plan, work instructions, and an appropriate training plan for employees, because without this training the system do not work properly and not conformities and accidents could happen.

Oil and gas exploration and production (E\&P) activities are responsible for serious accidents around the world, which in some cases were irreversible for the environment. The risks from these activities have been providing changes in legislation, which has become more rigorous and specific in this sector, especially in waste management.

The controls in this sector include appropriate procurement of inputs, reduction in waste generation, optimization of products, as well as the processes of packaging and storage, transportation, and proper final disposal of waste.

An important point in waste management processes is the monitoring of all waste stages, from generation to final disposal, ensuring that all related companies in the process are qualified and licensed by the environmental authorities.

Hazardous waste need to more attention and specific protection controls because of their contamination risks. In case of accidents and spills, these wastes could cause environmental damage and serious health problems. In addition, the supervision with this type of waste is much bigger, and the penalties for non-conformances are stricter [2].

Periodically, environmental authorities conduct inspections and audits to verify documentation, processes, procedures and the requirements of applicable law. Because of that, companies need to establish an efficient and complete management system, preventing possible environmental problems and penalties.

The aim of this work is to explain the offshore waste management system, introducing the procedures and controls according to the requirements of the Brazilian Guideline for Environmental Audits, DZ-056-R.3 [3], applicable to the State of Rio de Janeiro. 


\section{Offshore Activity in Brazil}

The history of oil in Brazil begins in 1858, through Decree 2266, signed by the Marquis of Olinda, allowing José Barros Pimentel to extract bituminous mineral for the manufacture of kerosene on the banks of the Rio Marau, located in the State of Bahia.

The following year, the Englishman Samuel Allport, during the construction of Brazilian Eastern Railway, observed oil drip in the neighborhood of Lobato, in Salvador city, capital of Bahia [4].

The first exploration directly related to oil occurred in 1891 in the state of Alagoas, and the first Brazilian oil well was drilled in 1897, in Bofete city, State of São Paulo, reaching a depth of 488 meters, with a production of $0.5 \mathrm{~m}^{3}$ of oil [4].

In 1953, during the government of President Getúlio Vargas, was instituted the state oil monopoly with the creation of PETROBRAS that powering the research of oil in Brazil [4]. PETROBRAS monopolized for over 40 years the exploration, production, refining and transportation of oil in Brazil, however in 1997 began to compete with other foreign and national firms, due to the Brazilian Federal Law 9678 [5], signed by President Fernando Henrique Cardoso, which among other measures instituted the National Petroleum Agency, and allowed the oil and gas exploration and production by multinational companies, promoted a great expansion in the offshore activities in Brazil [6].

Nowadays, the advances of these activities have leveraged the national economy, especially in the areas of large offshore reserves, as the states of Rio de Janeiro and Espírito Santo.

According to information from the Bulletin of Oil and Gas [4], issued by the National Petroleum Agency in May 2013 , the total of exploration concessions was 314 (232 onshore and 82 offshore) operated by 26 companies. In this period, oil production was $1,993 \mathrm{Mbbl}$ (thousand barrels) per day and gas production was 74.9 million $\mathrm{m}^{3}$ per day.

The figures 1 and 2 below [7], from the Bulletin of the Oil and Gas, present the history of oil and gas in the period

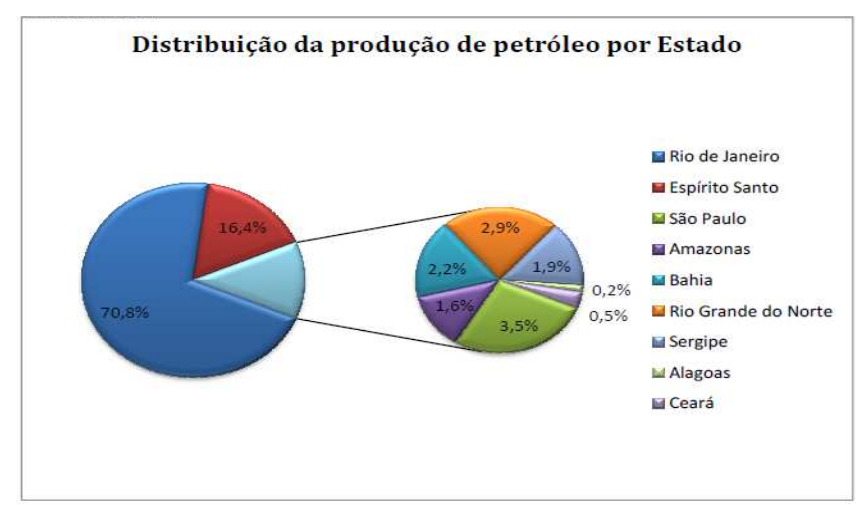

Figure 1. Oil and gas production historical.

between May 2012 and May 2013. Comparing the results of May 2013 with April 2013, oil production has increased by $3.7 \%$ and gas production increased by $0.2 \%$. In addition, comparing the results of May 2013 with May 2012, the production of oil was reduced to $2.7 \%$ and gas production was increased by $9.4 \%$.

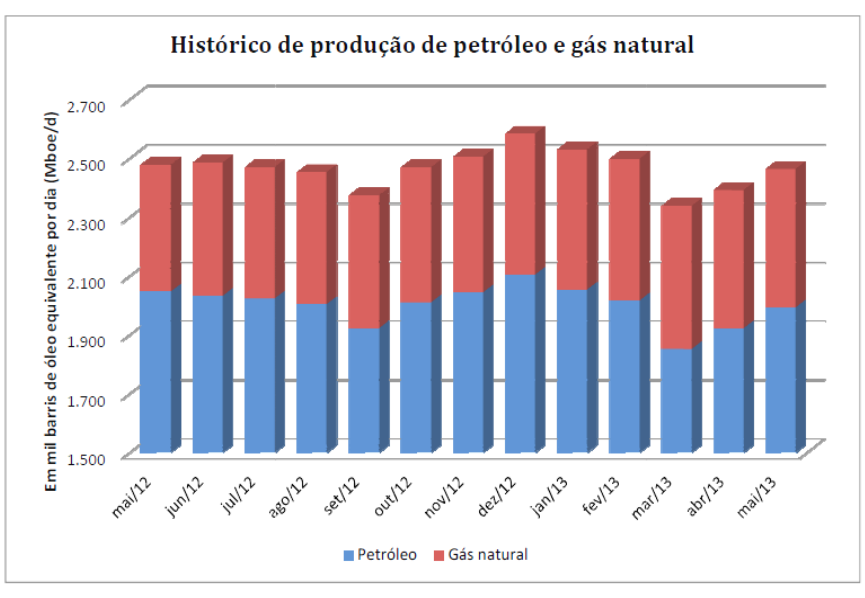

Figure 2. Ddistribution of oil production in Brazil

In Brazil, offshore activities are controlled by specific agency: IBAMA (Brazilian Institute of the Environment and Renewable Natural Resources). This agency issues the authorization (operation license) necessary of exploration and production of oil and gas companies and establishes a series of environmental conditionals and programs to prevent damages and preserve the quality of the environment.

In 2011, IBAMA established the Technical Note 01 for implementation of Pollution Control Project (PCP) required in the processes of environmental licensing of companies for maritime exploration and production of oil and gas as well as for the presentation of the goals of this project and its implementation reports.

The PCP is one of the mitigating impacts measures required as determinant of environmental license regarding the three activities: seismic research, drilling and production and flow. This project consists of a set of procedures, both on board and off the vessels and offshore units, in order to minimize pollution from: waste generation on board their disposal onshore, the disposal of waste at sea and atmospheric emissions [8].

The next chapters will address the management system of waste offshore, based on Brazilian Guideline for Environmental Audits, DZ-056-R.3, applicable to the State of Rio de Janeiro, addressing the types of waste generated and the applicable procedures and treatments.

\section{Offshore Waste Types}

\subsection{Waste Classification}

In Brazil, the Technical Standard NBR 10004/2004 classifies the waste according to their characteristics and pollution potential, presenting two classifications:

- Class I (hazardous waste); and

- Class II (non-hazardous waste). 
Class I is applied to waste that have characteristics like dangerousness, flammability, corrosivity, reactivity, toxicity and pathogenicity, providing risks to public health and the environment.

Class II has two sub-classes:

- Class IIA (non-inert): waste which is soluble in water and have biodegradability and combustibility properties.

- Class IIB (inert): waste that does not cause alterations in the parameters of appearance, color, turbidity, hardness and taste, when in contact with water.

\subsection{Offshore Waste Types}

Offshore activities are responsible for the generation of waste class I and class II, mainly class I (hazardous waste), because of the oil and gas exploration. Class II waste is mostly generated by administrative and domestic activities.

The topic 5 describes some examples of this waste in Table 1.

Offshore waste types are defined by some characteristics like classification, physical conditions, size, chemical compounds and pollution potential.

The large variety of offshore waste could be very dangerous to environment and public health, mainly hazardous waste. According to Brazilian National Waste Plan, in 2008, the sector of exploration and production of oil and gas generated approximately 34,000 tons of hazardous solid waste. In 2009, the generation was 39,000 tons and in 2010 it was 51,000 tons. Therefore, their correct management and destination is so important.

It is necessary to separate the materials in accordance with their classification, type and compatibility to ensure the safety of the storage, preventing accidents and environmental damages.

In Brazil, all of the offshore waste management activities are controlled by specific agency: IBAMA (Brazilian Institute of the Environment and Renewable Natural Resources). This agency issues the authorization (operation license) necessary of exploration and production of oil and gas companies and establishes a series of environmental conditionals and programs to prevent damages and preserve the quality of the environment.

The following topics will describe rules and parameters presenting in Brazilian Guideline for Environmental Audits, DZ-056-R.3, for each type of waste generated by offshore activities.

\section{Offshore Waste Management}

\subsection{DZ-056-R.3}

The Brazilian Guideline for Environmental Audits, DZ-056-R.3 aims to establish responsibilities, procedures and technical criteria for conducting environmental audits, as an instrument of environmental licensing system, for the State of Rio de Janeiro.
These environmental audits are conducted by an audit team that has the purpose of verifying conformances with the requirements established by the DZ-056-R.3. At the end of audit, the results are communicated through a report, for which action plans are prepared, establishing deadlines and responsibilities to solve the non-conformances highlighted

Environmental audits have the following modalities:

- Environmental Audit of Control: usually held when requested or in cases of renewal of environmental license, to detailed verification of the organization's environmental performance.

- Environmental Audit of Monitoring: performed each year, with an emphasis on the Plan of Action of the last environmental audit, complementing it with new measurements from any requirements of the environmental agency, significant changes in the environmental aspects and impacts and changes in the process, among others.

The obligation of environmental audits depends on the size and the polluting potential of the company.

Some examples of organizations with this obligation are:

- Refineries, pipelines and oil terminals and their derivatives;

- Port facilities;

- $\quad$ Air service facilities (airports, flying clubs);

- Facilities for the storage of toxic and hazardous substances;

- Facilities for processing and final disposal of toxic and hazardous waste;

- Units of power generation from thermal sources;

- Facilities for treatment and final disposal of domestic wastewater;

- Petrochemical and steel industries;

- Chemical and metallurgical industries;

- Facilities for processing, recovery and disposal of radioactive waste;

- Mineral extraction activities (except the minerals of direct application in civil construction);

- Mineral beneficiation activities;

- Treatment facilities for wastewater;

- Pharmaceutical and veterinary products industries;

- Textile industries;

- Production of sugar and alcohol;

- Shipyards; among others.

The DZ-056-R.3 refers some basic requirements regarding waste management. The following these requirements will be presented.

\section{A. Layout of the Waste Management System}

This requirement is very important to organize all of waste management areas and equipment used at the company.

The layout includes the steps of: generation, segregation, transport, and storage of waste class I and class II.

And the company needs to have specific areas for waste storage; waste processing equipment; and specific areas for waste disposal. 


\section{B. Waste Inventory}

Waste inventory is a tool for waste management regulated by the Brazilian Resolution of the National Council of the Environment: CONAMA 313/2002.

In this document, the company needs to report information about the generation, characteristics, storage, transport, treatment, reuse, recycling, recovery and final disposal of all of waste generated.

\section{Waste Stream}

This requirement is important because it ensures the traceability of all stages of waste management.

The waste stream needs to include information from the point of generation to final disposal, considering:

- The adequacy and safety containment systems;

- Intermediate storage and final disposal;

- The adequacy of the procedures for the choice of treatment and disposal contracts;

- The existence of the environmental license, which is valid and compatible with the type of waste to transporters and receptors; and

- The use of Waste Manifest.

\section{Responsibilities and procedures}

The responsibilities and procedures for the waste management need to be defined by the company, to ensure the efficiency of the system, as well as greater control and functionality of it.

\section{E. Plans and Programs}

The company needs to establish plans and programs for waste reduction as well as to apply reuse and recycling practices.

These requirements are also present in the Brazilian Federal Law 12305/2010, which established the National Policy of Solid Waste.

\subsection{Stages of the Waste Management System}

Waste management system includes the stages from generation to final disposal of waste.

After generation, waste has to be classified, named, packaged and stored in equipment for transportation, for subsequent final disposal. In topic 5, the table 1 describes the main waste generated in offshore activities and their descriptions. In the following figure, will all stages of offshore waste management system

The generation of waste from offshore activities, happens through several processes, as drilling, maintenance, industrial assembly, civil construction, industrial cleaning, storage of materials, administrative activities, waste storage, medical clinics, general services and laboratories.

The Brazilian Technical Standard NBR 10004/2004 defines the stages of classification, physical state and nomenclature of waste, according to their characteristics and compositions.

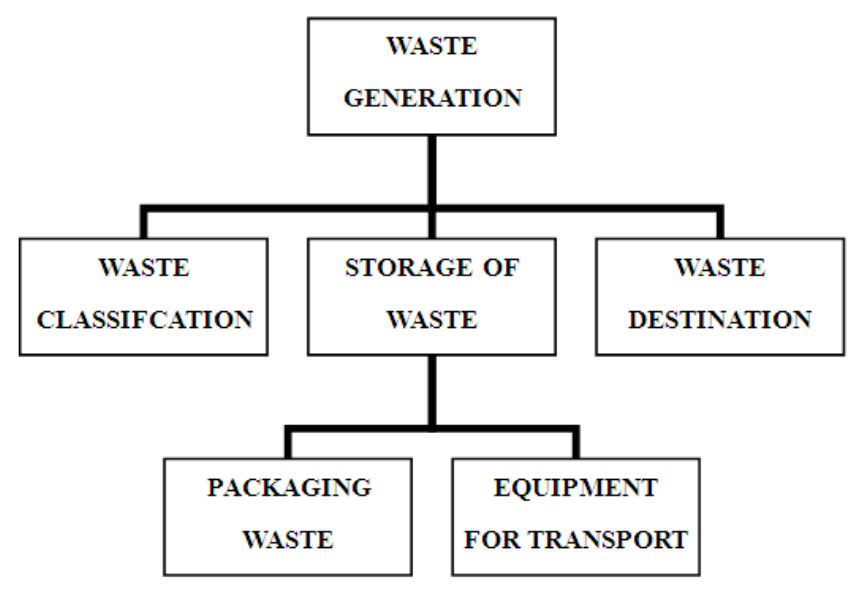

Figure 3. Stages of the offshore waste management system.

After the classification, each type of waste has to be packaged, avoiding contaminations and blends of them.

Companies need to have an area for waste storage, which have to be divided by the type of waste, according to their class and physical state.

Wastes need to be packaged and stored properly to avoid irregularities during the transport of waste. For liquid waste, the packaging has to include a containment basin, and it is very important to pay attention to the sealing of the containers to prevent leaks. Organic wastes have to be stored in refrigerated containers to prevent odors and leaks on shipping. In addition, health service wastes have to be packaged and identified in white containers as stipulated by the National Agency for Sanitary Surveillance (ANVISA).

In the transportation of waste, all containers must be labeled properly with information about the residue stored. For hazardous waste must be established specifics emergency chips for each type of waste.

\section{Treatment of Wastes}

The choice of the most appropriate treatment for each type of waste, must take into consideration factors such as its classification, composition and the cost of disposal [9].

Table I below shows the main waste from offshore activities, and the possible treatment technologies applicable

As established in Brazilian Guideline for Environmental Audits, DZ-056-R.3 and in the Brazilian Federal Law 12305/2010, with the National Policy of Solid Waste [10], companies must establish programs to reduce waste and implement recycling and reuse practices. Thus, the volume of waste disposed of in landfill is reduced, and other alternative treatments, such as physical, chemical, thermal or biotechnology, are being used, in order to reduce environmental impacts.

According to the Brazilian National Waste Plan, recycling and reuse are the most alternatives used by the sector of exploration and production of oil and gas for solid waste final disposal.

Recyclable waste (paper, plastic, glass and metal) are generally sent for recycling, and non-recyclable waste are 
sent to landfills.

Hazardous waste needs further attention because their treatments are usually more complex and incorrect disposal of this waste can result in irreversible environmental damage [11].

In some cases is possible to incorporate hazardous waste in some industrial processes. As the case of the cement industry, that use these waste for co-processing in the cement manufacturing process. In addition, ceramic industries can use these waste for the manufacture of ceramic artifacts.

Table 1. Main waste from offshore activities

\begin{tabular}{|c|c|c|c|}
\hline Waste & Class & Physical state & Possible treatments \\
\hline Batteries & I & Solid & Industrial landfill (class I) / Reprocessing \\
\hline Chemical waste & I & Liquid / Solid & Industrial landfill (class I) / Co-processing \\
\hline Civil constructions waste & IIB & Solid & Industrial landfill (class II) / Recycling \\
\hline Drums & I & Solid & Industrial landfill (class I) / Reconditioning \\
\hline Electronic waste & I & Solid & Industrial landfill (class I) / Recycling \\
\hline Fireworks & I & Solid & Detonation \\
\hline Fluorescent light bulbs & I & Solid & Industrial landfill (class I) / Decontamination \\
\hline Gas cylinder & I & Solid & Reverse logistics \\
\hline Glass & IIB & Solid & Recycling \\
\hline Hazardous waste & I & Solid & Industrial landfill (class I) / Co-processing / Incineration \\
\hline Health services waste & I & Solid & Incineration \\
\hline Metal & IIB & Solid & Recycling \\
\hline Non-recyclable & IIA & Solid & Sanitary landfill (class II) \\
\hline Organic waste & IIA & Solid & Sanitary landfill (class II) \\
\hline Paper & IIA & Solid & Recycling \\
\hline Plastic & IIA & Solid & Recycling \\
\hline Print cartridges & I & Solid & Industrial landfill (class I) / Recycling \\
\hline Waste oil & I & Liquid & Industrial wastewater treatment station / Co-processing \\
\hline Wastewater & I & Liquid & Industrial wastewater treatment station \\
\hline Wood & IIA & Solid & Energy Recovery \\
\hline
\end{tabular}

\section{Conclusions}

The oil and gas industry is related to many environmental disasters, especially in cases of oil spills at sea, resulting in environmental damage and economic losses to companies.

In addition of that, the bad waste management in this sector is also responsible for extensive damage to the environment [12]. These scenarios promoted advances in environmental legislation, which became more specific and restrictive.

In this context, in 1995, was created Brazilian Guideline for Environmental Audits, DZ-056, applicable to the State of Rio de Janeiro. Nowadays, this directive is in its third revision, dated on May 7, 2010, which among other parameters evaluates the legal compliance of waste management applied in enterprises.

Waste management system has to include reuse and recycling practices, as well as waste reduction policies. Companies should also opt for alternative disposal technologies, in other to reduce the waste disposal in landfills.

The proper disposal of waste may represent increases in costs for companies, thus the implementation of some measures can help to reduce these costs.

These measures include:

- Identification of critical areas, to establish goals for reducing waste generation;

- Identification and establishment of practices for reducing waste in production processes;

- Storage of waste in accordance with their rating and physical states, avoiding the contamination between non-hazardous waste with hazardous waste, that have a more expensive treatment;

- Implementing practices of waste selective collection for recycling;

- Promoting appropriate packaging waste, avoiding leaks and environmental damage;

- Using transport and waste disposal companies qualified and licensed by the Environmental Agency, preventing possible environmental problems and penalties.

Other important tools for the success of that system are training and awareness of employees for the damage from these activities. Conscious workers will be able to 
understand better the importance of proper waste management, and will be more attention on compliance procedures and controls, as well as helping in the evolution of the system, and thus its efficiency is preserved.

Thus, the system of waste management is very important for the oil and gas industry, because it ensures legal conformity of operations, preventing possible penalties by the Environmental Agency, and promotes practices to reduce and reuse in the input consumption and waste generation, providing economic and environmental advantages for companies.

\section{References}

[1] A. Barker, C.Jones, "A Critique of The Performance of EIA Within the Offshore Oil and Gas Sector.pdf," Environmental Impact Assentment Review, Vol.43 31-49 (2013).

[2] M. D. LaGrega, P. L. Buckingham, J. C. Evans, Hazardous Waste Management, published by Waveland Press, 2nd Revised edition, USA, (2010).

[3] State Council of Environment, "Guideline for Environmental Audits, DZ-056-R.3”, 1-19 (2010).

[4] J. E. Thomas, "Fundamentals of Petroleum Engineering",Vol.2 3-4 (2004).

[5] Presidency of the Republic. "Brazilian Federal Law $N^{\circ}$. 9478", Provides for the national energy policy, the activities related to the petroleum monopoly, establishes the National Council of energy policy and the Petroleum National Agency and other provisions, (1997).
[6] G. B. Santos, "Wastes Management in The Oil Industry: Attending of The Environmental Permitting Requirements in Brazil", 2013 South American/Caribbean Region SPE Student Presentation/Paper Contest, (2013).

[7] National Petroleum Agency, "Bulletin of Oil and Gas", 5-26 (2013).

[8] Brazilian Institute of the Environment and Renewable Natural Resources - IBAMA. "CGPEG/DILIC/IBAMA No 01 ", Guidelines for presenting, implementing and preparing reports in the process of environmental licensing of the offshore exploration and production of petroleum and gas ventures, 3-34 (2011).

[9] Woodard \& Curren, "Industrial Waste Treatment Handbook", published by Butterworth- Heinemann Ltd, 2nd Revised edition, USA, (2006).

[10] Presidency of the Republic. "Brazilian Federal Law No. 12305", Provides The National Policy of Solid Waste, (2010).

[11] L. P. Jackson, A. R. Rohlik, R. A. Conway, "Hazardous and Industrial Waste Management and Testing", 3rd Symposium, ASTM Special Techniques Publication 851, ASTM, Philadelphia, PA, 48-60 (1984).

[12] M. I. P. Ferreira, R. Costa, P. Almeida, M. Cordeiro, M. A. V. Ferreira, U. Mayerhofer, "Society of hydrocarbons: problems with economical heating generated by the supply chain of oil and gas in Macaé-RJ," Social, environmental and urban impacts from the oil and gas activities: the case of Macaé, Fluminense Federal University, 169-187 (2010). 